\title{
CUSTOMER SATISFACTION WITH SERVICES OF LOW-COST CARRIERS AT PULA AND ZADAR AIRPORTS
}

\author{
Dora Naletina * \\ Mate Damić ${ }^{* * *}$ \\ Anela Jabučar ${ }^{* * *}$
}

\begin{abstract}
Air transport is the newest form of traffic branch and, in today's modern conditions, it advances very quickly. Basically, air transport provides passenger transportation, especially to far-away destinations, because of its greatest advantage - speed of travel. Due to globalization, the air transport market is characterized by strong competition, and the liberalization of the Croatian air transport industry has contributed to the increased utilization of international passenger transport. Precisely as a result of the aforementioned influences, air transport requirements in Croatia are experiencing higher growth. The dependence on air transport and tourism is increasingly necessary and of great economic importance. With the emergence of low-fare airlines on the Croatian market, passengers have more choices and opportunities than ever before. With their presence on the market, low-cost carriers have greatly influenced the air transport market and contributed to the growth of passenger traffic. This paper aims to explore passengers' satisfaction with low-cost carriers. The results of primary research show that passengers who travel with low-cost carriers place high importance on pricing, ticket availability and destination availability, and are satisfied with the service they receive in comparison to the ticket price. Passengers place importance on how quickly they can buy tickets online and the availability of various payment options.
\end{abstract}

KEYWORDS: air transport, air carrier, low-cost carriers, airports, customer satisfaction

\footnotetext{
Assistant Professor at Department of Trade and International Business, Faculty of Economics and Business, University of Zagreb; dora.naletina@efzg.hr.

** Assistant Professor at Department of Trade and International Business, Faculty of Economics and Business, University of Zagreb; mdamic@efzg.hr.

**** Management assistant, Eol Group Ltd; anela.jabucar@gmail.com.
} 


\section{INTRODUCTION}

Due to new modern technologies, air transport has been evolving rapidly. Because there are so many different users, it is important to understand what they want and adjust the services to their needs. The air transport development has boosted demand for air transport services globally, along with the need to establish a more effective process of air transport, and passenger and cargo services. Air transport, like all other traffic branches, creates benefits for economy but also brings different setbacks. In relation to other traffic branches, modern air transport definitely stands out with its speed and considerably more safety for the goods, especially if high-value goods are transported (European Commission DG Mobility and Transport, 2017). ${ }^{1}$

The development of low-cost air transport in Europe starts with the process of liberalization of air transport in the 1990s. The first large low-cost carriers developed in the countries where there existed the tradition of charter flights. Around twenty years later, low-cost air transport in Europe is still characterized by constant development dynamics and change. Every year, many companies disappear from the market, while new ones emerge. Low-cost carriers are still relatively poorly represented in the countries of Central, Eastern and South-eastern Europe, but this trend has been changing in the last years. ${ }^{2}$ Lowcost carriers occupied more than $36 \%$ of the market in 2018, which is the biggest share yet, and it is estimated that, in 2027, the share will rise up to $50 \%$. Since 2009, the market share of all the low-cost carrier seats in Europe has been growing annually by 1.4 percentage points. ${ }^{3}$

Regional airports depend on carriers. That is the reason why switching to lowcost carriers can represent some challenges for the economies involved, especially because of legacy carriers ${ }^{4}$. Regarding the Croatian air transport market, it is evident that the capacities rise to a great extent during the summer months. In the summer of 2019, the five busiest airports in Croatia were serviced by the

\footnotetext{
1 https://ec.europa.eu/transport/modes/air/25years-eu-a European Commission DG Mobility and Transport, 2017. Available at: https:/ec.europa.eu/transport/modes/air/25years-eu-aviation_en (October, 12, 2019).

2 Gašparović, S., Jakovčić, M., Vrbanc, M.: Hrvatske zračne luke u mreži europskih niskotarifnih kompanija, Geoadria, 17(1) 2012, pp. 93-109.

3 Anna Aero, 18.07.2019, https://www.anna.aero/2018/07/18/lcc-capacity-in-europe-set-forhalf-a-billion-seats-in-2018/ (September 3, 2019).

4 Akgüç, M., Beblavý, M., Simonelli, F.: Low-Cost Airlines. Bringing the EU closer together, Brussels: Centre for European Policy Studies, 2018. Available at: https://www.ceps. eu/wp-content/uploads/2018/05/LowCost\%20Airlines\%20Bringing\%20the\%20EU\%20closer\%20together.pdf (October 17, 2019).
} 
three largest low-cost carriers in Europe: easyJet, Norwegian Air Shuttle, and Ryanair. During July and August, easyJet realized over 3.100 flights in Croatia and, when compared to the summer of 2018, more than doubled its capacity in Zadar Airport ${ }^{5}$ Since over the last years Croatian air transport market has been characterized by the entrance of more and more low-cost carriers, the goal of this paper is to analyses users' satisfaction with the services of low-cost carriers, especially focusing on Pula and Zadar Airports which have recorded a considerable growth over the last years. The paper aims at providing recommendations on how to offer better service and satisfy the passengers, users of low-cost carrier services.

After the introduction, the characteristics of low-cost carriers and their strategies will be explained in more detail.

\section{LOW COST CARRIERS}

\subsection{CHARACTERISTICS OF LOW-COST CARRIERS}

Low-cost carriers are those airline companies that provide services of transportation at considerably lower prices which are a product of cutting down business operating costs. The elements that enable lowering the costs are numerous and can be divided into three basic groups, the so-called three simplicities: the simplicity of the product, the simplicity of the services and the simplicity in the organization. ${ }^{6}$ Low-cost carriers attract users with their affordable prices and, in that way, increase their market share. Lately, their importance has been continuously growing and they have been exerting pressure on traditional airline companies to consider their business model. ${ }^{7}$ A low-cost carrier or a lowcost airline company, also known as a discount or a budget airline company, is an airline company that generally offers low prices by eliminating many traditional passenger services. This concept, first introduced by Pacific Southwest Airlines in the early 1950s, has created one of the greatest success stories in air travel industries in the last 20 years. Southwest Airlines started the business in 1971, and the Irish Ryanair followed its model in the 1990s. After 1995, the British easyJet (the second largest LCC in Europe) started operating in Europe. Many countries have liberalized their markets (domestic and international),

5 https://www.exyuaviation.com/2019/07/low-cost-carriers-drive-croatias-record.html (October 24, 2019).

6 Pender, L., Baum, T.: Have the frills really left the European airline industry?, International Journal of Tourism Research, 2(6) 2000, pp. 423-436.

7 Naletina, D., Petljak, K., Sremac, M.: Empirical research on user satisfaction with the transport and supporting services at Croatian airports, Pomorstvo, 33(1) 2019, p. 304. 
after the deregulation of American domestic companies in 1978. The product LCCs offer is "just" the flight service and nothing more. If you wish to add on baggage and have food and beverages on the plane, you have to pay for them additionally. ${ }^{8}$

Low-cost carriers emerged in the 1990s with the specific goal of operating with lower costs than their traditional rivals. Greater efficiency and savings are achieved in different ways, most significant of them being better capacity utilization (of both the planes and the crew), one class service, one airplane type, selling tickets directly to the passengers, using smaller airports, no meals or beverages included in the ticket price. Low-cost carriers provide more choice to the passengers than ever. It is clear that passengers who use low-cost carriers consider the price to be a very significant factor. It is expected that these companies will continue to entice those passengers that travel for work, but also those than travel on holidays, and that they will have a growing influence on the choice of destinations. ${ }^{9}$ The importance of LCCs in Europe started to grow with the liberalization of air transport. First low-cost airlines in Europe emerged in Ireland and Great Britain. ${ }^{10}$ It can be said that in Europe, there are two low-costs models: easyJet and Ryanair. Ryanair services secondary airports, with not many flights, and focusing on new tourist markets without direct competition. On the other hand, easyJet operates on the primary, expansive airports, with frequent flights and orienting towards the existing markets (business and leisure travelers), but new markets as well, accepting the competition. Other airlines are simply trying to follow one of these two leading models.

Low-cost carriers are usually present on shorter routes (mostly under 1,500 $\mathrm{km})$. To realize the necessary low operating costs per passenger, it is necessary that airplanes have as many seats as possible. Competitive advantage derived from higher efficiency of the airplanes is of great importance and is achieved through a combination of several factors: using secondary airports and offering the service of connecting two destinations directly. Secondary airports have two main advantages in relation to bigger airports: they charge cheaper fees to airlines for using their services and, since they are less frequented, there are fewer delays caused by "congested" airports. Moreover, low-cost carriers use one airplane type. In this way, the pilots and the cabin crew can work on

\footnotetext{
8 Sarilgan, E. A.: Impact of low Cost Carriers on Turkish Tourism Industry, Internationa Journal of Academic Research in Business and Social Science, 6(4) 2016, p. 180.

9 Vojvodić, K.: Europsko tržište niskotarifnih zračnih prijevoznika, Suvremeni promet, 26(5) 2006, pp. 364-366.

10 Gašparović, S., Jakovčić, M., Vrbanc, M.: Hrvatske zračne luke u mreži europskih niskotarifnih kompanija, Geoadria, 17(1) 2012, pp. 93-109.
} 
every plane in the fleet. LCCs have also used price structure simplification, like setting the price for one direction, based on the offer and demand and the principle that customers pay less if they book the flight earlier. The main reason why low-cost carriers manage to attract passengers is great flexibility and, essentially, low prices. To ensure their long-term survival, LCCs have to do two things: first, they have to preserve their competitive advantages in relation to their conventional competitors. This means they have to bear in mind and focus on the most important features of their low-cost product; secondly, they should become a number one or a number two in the market share. This domination, in combination with low prices, not only provides a powerful, protected position in case new competition enters the market, but also ensures a stable flow of funds for the necessary further development. ${ }^{11}$

\subsection{STRATEGIES IN LOW-COST AIR TRANSPORT}

Development of low-cost carriers in the last few years has surely revolutionized the air transport industry in all its sectors (airline companies, airplane manufacturers, air traffic controllers and airports). For airports, the effect of attracting LCCs can be summed up in four main areas: marketing, finances, business operations and capital investments. Some regions, especially in Europe, have undergone major transformations from a relatively unknown destination into a tourist center attractive to passengers throughout the year, this being a direct result of LCCs emergence on their airports. Successful development of low-cost airlines has imminently led to the concept of low-cost airports and low-cost terminals. Up until today, there has not been an airport built and developed to service low-cost carriers exclusively, however, many airports that had small or no commercial activity are now revived with the activities offered by LCCs. Also, many airports have developed passenger terminals designated for low-cost business model. The aim of low-cost airline companies is to maximize productivity and minimize costs, and in airports, this is usually achieved by minimizing the turnaround time and reducing the costs of using unnecessary infrastructure and services. ${ }^{12}$

The leading role in low costs is a strategy used by companies to achieve competitive advantage by reducing their costs more than their competition. In the existing literature, most authors point out that low-cost strategy focuses on achieving competitive advantage with lowest costs and cost structure in the

11 Vojvodić, K.: Europsko tržište niskotarifnih zračnih prijevoznika, Suvremeni promet, 26(5) 2006, pp. 364-366.

12 Graham, A., Papatheodorou, A., Forsyth, P.: Aviation and tourism: implications for leisure travel, 2008, Hampshire: Ashgate Publishing Ltd.. 
industry. The value chain is the basic tool for establishing the costs the competition. Some authors think that globalization and integration processes are the features of new strategies of many industries, which directly influences the development of the economies involved. In the long run, and viewed globally, air traffic is one of the economic branches that are developing very quickly in technological terms. The elements that accelerate this development are first and foremost seen in the development of computer science and telecommunications and the development of modern airplane engines that are fuel-efficient, but increase the range and the speed. ${ }^{13}$

From the carriers' perspective, the main goal in servicing is to maximize profitability by using the available capacities, which is usually expressed through the load factor. Transport companies can maximize passenger flow by reducing the costs and prices of their products or services to achieve competitive prices. Some passenger markets are very sensitive to prices, meaning that consumers can easily be persuaded to choose another airline or mode of transport if the price grows above the critical level (demand for travels like ,coach express" targeting young travelers services is an excellent example of price-sensitivity)..$^{14}$

There are different approaches to competitive strategies. Low-cost strategy and value chain represent starting points in low-cost air passenger transport. Cost leadership is a strategy where a company tries to remain the one with the lowest costs in its industry. A company that uses the strategy of cost leadership has a wide range of activity and services many segments in the industry, and can even do business with other related industries. The size of the company is often very important for its cost advantage. For the low-cost strategy to work for the suppliers, the managers have to carefully re-examine every activity that generates costs and establish what drives the costs. They have to be proactive in restructuring the value chain to eliminate unnecessary steps and low-value activities. Building competitive advantage directly depends on the way how a company manages its value chain in relation to the value chains of its competitors. The value chain is a systematic way of studying all the activities that a company performs and the form of their interaction with the aim to analyses the source of competitive advantage. Value chain shows total value that a company creates. The concept is based on monitoring the company as a collection of separate, but connected activities used to create value for the customers i.e. used to shape, manufacture, advertise, sell and distribute products or services.

\footnotetext{
13 Krajnović, A., Bolfek, B., Nekić, N.: Low-cost strategija u zračnom prijevozu putnika, Oeconomica Jadertina, 4(2) 2014, p. 4.

14 Page, S.: Transport and tourism: Global perspectives, 2005, Harlow: Pearson education, p. 21.
} 
A company is divided into strategically important activities in order to understand the behavior of the costs of possible sources of differentiation. ${ }^{15}$

The way airlines form their prices is a complicated process, with many different ticket prices, available according to the time of the travel (season, off-season), class, duration and whether the travel includes a Saturday evening in Europe. Moreover, the price depends on the place where it is bought, along with many other factors. ${ }^{16}$ Although there are differences in prices at specific routes, the price span usually narrows down with the flight being longer, so the price per kilometer is lower at longer routes than at shorter ones. For example, ticket prices in Europe are higher per kilometer than in North America, and the prices on the routes between Europe and Asian-Pacific area are lower than between Europe and Africa. ${ }^{17}$

There are only two types of low-cost carriers, those who follow Ryanair and those who follow easyJet. Ryanair cooperates only with secondary airports with relatively small number of flights and focuses on new markets without direct competition. It focuses the attention first and foremost on the costs, which includes putting much pressure on the airports and the suppliers to lower their costs. EasyJet focuses its attention on bigger airports with more traffic and the existing and new markets, accepting the competition. Other LCCs follow one of these two examples, although they strive to be the offspring of those large airlines, which deprives them of the advantage of having low costs like Ryanair and EasyJet. ${ }^{18}$

The number of reservations and actual travels can vary, which suggests that airlines have to form their prices according to the price sensitivity of the market to ensure that the sales price and the price of the seat increase the return for every departure. Different strategies of forming prices include: ${ }^{19}$

- uniform price, where the same price is charged to all the passengers on the flight

- different prices that include market segmenting and offer empty seats at lower prices

15 Krajnović, A., Bolfek, B., Nekić, N.: Low-cost strategija u zračnom prijevozu putnika, Oeconomica Jadertina, 4(2) 2014, pp. 5-6.

16 Hanlon, P.: Global airlines, 2006, Routledge.

17 Page, S.: Transport and tourism: Global perspectives, 2005, Harlow: Pearson education, p. 21.

18 Krajnović, A., Bolfek, B., Nekić, N.: Low-cost strategija u zračnom prijevozu putnika, Oeconomica Jadertina, 4(2) 2014, p. 7.

19 Page, S.: Transport and tourism: Global perspectives, 2005, Harlow: Pearson education, p. 21-22. 
- yield management, which includes planning and computer programming for optimization of revenue by choosing optimal combination of the travelers

- leg-based prices (price based on the initial and final destination), where the allocation of the seats is used for maximizing revenue on every segment of the flight and

- origin-destination price model, where complex techniques of linear programming are used to compare if multi-leg travel would generate more profit than single-leg travels, and in line with that, allocate the seats.

Europe is still the continent with the largest share of low-cost transport market. LCCs mostly dominate in airports, from where they depart and arrive at, and where they yield their negotiating power. Many airports rely on specific lowcost carriers for commercial survival. This ensures that airlines can dictate prices they will pay to the airport; otherwise, LCCs would relocate their operations somewhere else. Time is crucial in LCCs business, so these companies have to ensure that their airplanes are constantly on the move. ${ }^{20}$

\section{THE AIRPORTS IN PULA AND ZADAR}

Most travels on the LCCs are for leisure, which is a good motivator for the development low-cost transport in Croatian airports, especially those on the Adriatic coast. The second group is business motivated travels. The status of Croatian airports as "business" or "tourist" destination can indirectly be read out from the flight schedule. ${ }^{21}$

\subsection{PULA AIRPORT}

Pula Airport is situated on Valtursko polje, and the first take-off was recorded already in 1911, while civil flights started in 1924, flying to Trieste, Opatija and Ancona. ${ }^{22}$ Pula Airport is one of nine airports and the fourth busiest in Croatia. By the end of 2009, Pula Airport was operating with LCCs: Ryanair,

\footnotetext{
20 Manuell, R.: 8 reasons low cost carriers are so cheap (2017), 01.03.2017. Available at: https://www.internationalairportreview.com/article/32697/low-cost-carriers/ (September 4, 2019).

${ }^{21}$ Gašparović, S., Jakovčić, M., Vrbanc, M.: Hrvatske zračne luke u mreži europskih niskotarifnih kompanija, Geoadria, 17(1) 2012, p. 103.

22 Naletina, D., Petljak, K., Sremac, M.: Empirical research on user satisfaction with the transport and supporting services at Croatian airports, Pomorstvo, 33(1) 2019, p. 303.
} 
Germanwings and Norwegian Air Shuttle. The arrival of low-cost carriers in Pula Airport is most responsible for the sudden growth of passenger traffic in 2006 , continuing in the following years. ${ }^{23}$

In 2017, British Airways, after three extremely successful airline routes connecting London with Zagreb, Split and Dubrovnik, launched the fourth line of direct flights connecting Pula with Heathrow Airport in London. ${ }^{24}$ After record values being achieved in June, July, August and September in 2018, when Pula Airport, for the first time in history, reached the number of 100,000 passengers, there followed the successful October. On 18 October 2018, Pula Airport welcomed its 700,000th passenger, which has not been recorded since Croatia gained its independence (Total Croatia News, 17/October/2018). In relation to 2018, in 2019, there were $16 \%$ more passengers. The greatest growth was in April, about $60 \%$, then $35 \%$ in May, which is the result of the profound joint effort of the Airport management, the Tourist Board of Istria County and the hotel industry, therein boosting the pre- and post-season. Such growth was not expected in July and August, but in October, it again rose by around $30 \%$, which was balanced out to $10 \%$ at the end of the year. Therefore, the goal in 2019 is to achieve 770,000 passengers. ${ }^{25}$ Graph 1 shows passenger traffic in Pula Airport since 1987 - August 2019.

Into its flight schedule for 2019 to Pula, Jet2.com added Birmingham. The flights to Birmingham started on May 12 and ended on October 13, with once a week flights on Sundays. With Jet2.com, you can fly to five European destinations: London Stansted, Edinburg, Leeds Bradford, Manchester and Birmingham. EasyJet added Amsterdam and Geneva to its schedule for 2019 direction Pula. The flights for Amsterdam lasted from June 25 to September 1, twice a week, on Wednesdays and Sundays. Geneva flights started on June 26 and lasted till August 31 2019, twice a week, on Wednesdays and Saturdays. EasyJet connects Pula and eleven European airports: London Gatwick, London Southend, Paris CDG, Liverpool, Bristol, Milan Malpensa, Berlin Schonefeld, Berlin Tegel, Amsterdam, Basel and Geneva. ${ }^{26}$

23 Vidović, A., Steiner, S., Štimac, I.: Development potentials of low cost aviation in the Republic of Croatia, Promet - Traffic\&Transportation, 23(6) 2011, pp. 522.

24 Poslovni dnevnik: U Hrvatsku dolazi još jedan niskotarifni zračni prijevoznik, 03.07.2019. Available at: http://www.poslovni.hr/trzista/u-hrvatsku-dolazi-jos-jedan-niskotarifni-zracni-prijevoznik-354992 (September 3, 2019).

25 Glas Istre: Zračna luka Pula „napada“ lanjski povijesni rekord: Samo na krilima Easy Jeta ove godine stiže 150 tisuća putnika (2019), 27.06.2019, https://www.glasistre.hr/ pula/zracna-luka-pula-napada-lanjski-povijesni-rekord-samo-na-krilima-easyjeta-ove-godine-stize-150-tisuca-putnika-591669 (September 4, 2019).

26 Pula Airport, https://airport-pula.hr/ (August 8, 2019). 


\section{Graph 1. Passenger traffic in Pula Airport, 1987- 2019-08}

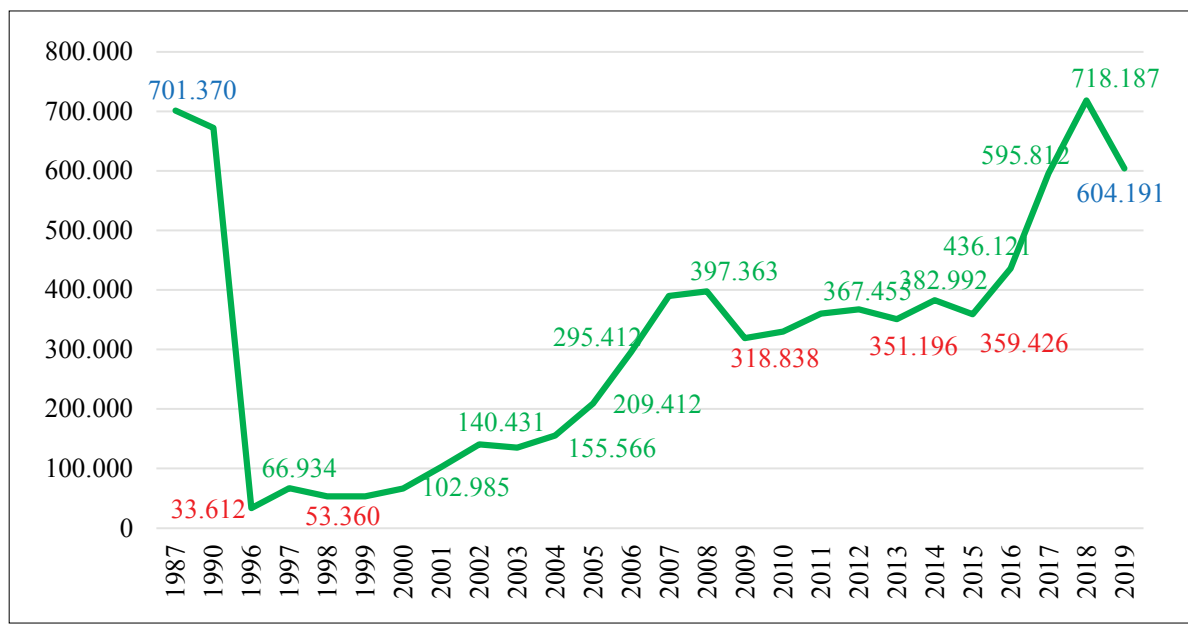

Source: Authors based on the data from Pula Airport, https://airport-pula.hr/poslovno/o-zracnoj-luci/statistika/ (September 3, 2019).

\subsection{ZADAR AIRPORT}

Zadar Airport (IATA identification code ZAD) is one of nine airports in Croatia. Founded in 1968, near the small town of Zemunik Donji, it is situated $7 \mathrm{~km}$ east of Zadar. It lies $88 \mathrm{~m}$ above the sea level. It is the biggest airport center in Croatia. Because there are two runways (vertically placed), it is able to accept airplanes in all weather conditions. It is specialized for accepting and maintaining firefighting airplanes (Canadair and Air tractors), being their mother airport. It is also the base of Croatian Airforce, certified for the training of professional pilots. It is equipped with: Mi-8, Mi-17, OH-58D, AT-802, CL-415, PC-9, Zlin 242, Bell-206B-3. Lufthansa Flight Academy InterCockpit also uses the facilities of Zadar Airport.

The importance of low-cost carriers in Croatian airports has been growing since 2008. The biggest growth in 2012 was recorded in Zadar Airport as the consequence of the introduction of new Ryanair lines between Zadar and London, Oslo, Stockholm, Bruxelles and Dublin (Gašparović, Jakovčić and Vrbanc, 2012: 105). Zadar Airport plays an important role in connecting northern Dalmatia and Lika with other parts of Croatia and the world, and it is also of great significance to Croatian Airforce. Due to new routes being introduced at the beginning of 2007, the building where passenger terminal is situated was expanded, which made Zadar Airport more suitable for accommodating more passengers. Zadar is a great starting point to any final destination. It is in the 
middle of the Adriatic, in the center of Dalmatia. Its geographical location guarantees quick access to one of the most renowned and attractive archipelago - NP Kornati islands, made up of 142 islands and islets. Zadar region has many marinas and is considered the nautical center of Dalmatia. ${ }^{27}$ Picture 1 shows the map of destinations of Zadar Airport.

Zadar Airport is the only Croatian airport that did not record a drop in the number of passengers during the recession in 2009. However, the real increase has been happening over the last years, and the number of half a million passengers was reached in 2016. The cause of this growth was the arrival of low-cost carriers. "With its model of cooperation marketing, working with Zadar authorities, Zadar County, Croatian Tourist Board and local tourist boards, Zadar Airport is the pioneer of introducing low-cost carriers in Croatia. Since then, Zadar Airport has been breaking records in passenger traffic year after year.” Irish Ryanair has mostly contributed to this development. It is the largest LCC in the world, and it first started operating in Zadar in 2007. After Ryanair had realized tourist potential of this airport, it opened the base in Zadar in 2012, and soon after, many other airline companies, like Lufthansa, Eurowings, easyJet, and Croatia Airlines started their expansion towards Zadar. Due to the growth, facilitated by the arrival of low-cost carriers, after only a couple of seasons, the recently renovated building with the passenger terminal had to be expanded and renovated again. The flow of passengers for the period between 2015 and 2019 (first 8 months) in Zadar Airport is displayed in Table 1. It can be observed that the biggest growth was achieved in 2017, and that in 2018, Zadar Airport for the first time exceeded the number of 600,000 passengers. If a longer period of time is observed, one can see that previously mentioned increase started in 2007, with the arrival of Ryanair, but with the reconstruction of the passenger terminal the growth was even $82.66 \% .^{28}$

27 Zadar Airport, https://www.zadar-airport.hr/ (August 8, 2019.).

28 Naletina, D., Petljak, K., Sremac, M.: Characteristics and the Overview of Air Traffic in the Republic of Croatia, Pomorstvo, 32(2) 2018, pp. 301-302. 
Table 1. Zadar Airport traffic statistics, 2015-2019-08

\begin{tabular}{|l|c|c|c|c|c|}
\hline Year & $\mathbf{2 0 1 5}$ & $\mathbf{2 0 1 6}$ & $\mathbf{2 0 1 7}$ & $\mathbf{2 0 1 8}$ & $\mathbf{2 0 1 9}$ \\
\hline Number of passengers & 487,652 & 520,226 & 589,468 & 604,039 & 594,314 \\
\hline $\begin{array}{l}\text { \% of the change in the number of passengers in } \\
\text { relation to the previous year }\end{array}$ & $0 \%$ & $6.68 \%$ & $13.31 \%$ & $2.5 \%$ & - \\
\hline
\end{tabular}

Source: Authors collection based on the data by Zadar Airport, https://www.zadar-airport.hr/ statistika-prometa (September 3, 2019)

On 13 August 2019, ACI Europe published their statistical reports for the first six months of this year. Zadar Airport was one of five busiest airports in Europe in Group 4 - Small reginal airports with up to 5 million passengers. In Group 4, from the beginning of the year, till 30 June 2019, Zadar Airport recorded second biggest growth in Europe, amazing growth of $37.6 \%$ in relation to the same period last year. The highest growth rate is recorded in Ohrid Airport, with even 62.9\%. In Group 4, in June this year, Zadar Airport is in the fourth place, with $41.8 \%$ in relation to June 2018. ACI EUROPE is a European regional organization that gathers 500 airports from 45 European countries. The members of this organization represent $90 \%$ of European commercial air traffic, with over 2.3 billion passengers, 21.2 million ton of goods and 25.7 million of airborne operations. ${ }^{29}$

In June, Zadar Airport served almost 124,000 passengers, which is the best monthly result in its history, and by $42 \%$ higher than the result in June 2018 . This year's June was the strongest month for Zadar Airport, which has reflected on the total half-year indicators. There was the total of 300,000 passengers, which is by $38 \%$ more than the same period last year. Just in June, Zadar Airport recorded 746 flights, around 170 more than in May this year, and considering the indications for the summer flight schedule, it is expected that positive trends will continue in the rest of the summer months. It is also expected that this trend will be mostly supported by Ryanair, the 12-year-long partner of Zadar Airport. This company connects Zadar with many European destinations like Berlin, Köln, Dublin etc. Zadar Airport has been developing cooperation with other low-cost carriers, like Eurowings, easyJet and Iberia Express. Iberia Express, as a part of the Spanish Iberia Group, connects Zadar with Madrid during the summer months. ${ }^{30}$

29 https://www.zadar-airport.hr/aci-zracna-luka-zadar-medju-5-najboljih-po-rastu-prometa (October 17, 2019)

30 Poslovni dnevnik: U Hrvatsku dolazi još jedan niskotarifni zračni prijevoznik, 03.07.2019, http://www.poslovni.hr/trzista/u-hrvatsku-dolazi-jos-jedan-niskotarifni-zracni-prijevoznik-354992 (September 3, 2019). 


\section{EMPIRICAL RESEARCH ON USER SATISFACTION WITH LOW-COST CARRIERS' SERVICE IN PULA AND ZADAR AIRPORTS}

\subsection{LITERATURE OVERVIEW}

In the last years many studies on low-cost air transportation have been published in domestic and scientific literature. In the following chapter, most relevant cognitions from the selected works in domestic and foreign scientific literature are presented.

Dobruszkes $^{31}$ (2006) conducts an analysis of European low-cost airline companies and their network. The author suggests that LCCs hold an important role on the market of Western Europe and point out how liberalization results in the development of low-cost carriers and in opening new routes. Furthermore, Štimac, Vidović, Sorić32 (2009) analyses the influence of low-cost carriers' business activities on air traffic of the Republic of Croatia, with special attention being given to the effects and development of Zagreb Airport. Based on the research results, they conclude that, in Croatia, the number of low-cost carriers will grow in the future, which will boost the traffic in airports. Gábor ${ }^{33}$ (2010) investigates how the expansion of the EU has changed the European market, focusing primarily on the changes in the network and the structure of the LCCs and establishing key differences among them, posing the fundamental question of the paper: What changes have influenced the expansion of the EU through the European network of low-cost carriers? In the conclusion of the paper, the author answers to the question by concluding that, since the expansion of the EU in 2005, the basic characteristics of the route network of LCCs have not changed considerably, although the networks have become denser and the number of destinations has increased.

Vidović, Steiner and Štimac ${ }^{34}$ (2011) define the criteria of modelling of the applicable low-cost activities in Croatian air transport in the relevant content of

31 Dobruszkes, F.: An analysis of European low-cost airlines and their networks, Journal of Transport Geography, 14(4), 2006, pp. 249-264.

32 Štimac, I., Vidović, A., Sorić, V. Utjecaj niskotarifnih zrakoplovnih kompanija na prometne učinke Zračne luke Zagreb, $12^{\text {th }}$ International Conference on Transport Science -ICTS 2009 -Transport science, profession and practice, 2009, Available at: https://bib.irb.hr/datoteka/409248.Utjecaj_niskotarifnih_zrakoplovnih_kompanija_na_prometne_uinke_Zrane_ luke_Zagreb.pdf (September 5, 2019).

33 Gábor, D.: Low-cost Airlines in Europe: Network Structures After the Enlargement of the European Union, Geographica Pannonica, 14(2) 2010, pp. 49-58.

34 Vidović, A., Steiner, S., Štimac, I.: Development potentials of low cost aviation in the Republic of Croatia, Promet - Traffic\&Transportation, 23(6) 2011, pp. 519-527. 
fleet management, route networking and traffic-technological processes. The paper analyses the dynamics of the operations of LCCs in the structure of air traffic in the Republic of Croatia and the influence on the status of the traffic at the airports and the national company. By testing the proposed model, the authors conclude that it is impossible to realize the propositions of the model, especially because of the financial aspect of such a project. However, it is possible to test the effectiveness of such a model in theoretical simulations. Despite many challenges, the low-cost business model is sustainable in Europe, like it has been in the USA for years. On the other hand, Gašparović35 (2011) analyses the influence of air traffic on tourism in coastal Croatian region of Primorska Hrvatska. The author sees the extreme seasonality which is in line with the tourist flow. In the pre- and off-season, conventional flights prevail. Special significance in air traffic of Primorska Hrvatska lies in the LCCs that are marked with highly prosperous development.

Bilotkach, Gaggero and Piga ${ }^{36}$ (2012) look into the presence of drops in prices over time as an indicator of an active "yield management" (a strategy based on the activity of selling the product or the service to the right client, at the right time and at the right price) of two leading European low-cost carriers that were observed daily from June 2002 till June 2003. The findings show how "yield" management is effective during the increment of the flight occupancy factor. Furthermore, the interventions made by the "yield" management intensify and exert a stronger influence on specific routes. If the pressure of competition drops, it enables the companies to adopt a more standard approach to price forming. The "yield" management interventions are more effective in the increment of occupancy factors on the routes where the combination of customers is heterogeneous (it includes passengers that travel in free time, for business or visiting family). The research is completed with the conclusion that on the market with a homogeneous customer base, no significant "yield" management is recognized. Krajnović, Nekić and Bosna ${ }^{37}$ (2016) confirm that lowcost air traffic has a positive influence on the economy, especially if viewed from the aspect of tourism. Since Croatia is a tourist country, it has especially influenced the development of certain airports, first and foremost those that are situated in Primorska Hrvatska. The market share of the LCCs in Croatia grew from $4 \%$ in 2004 to $36 \%$ in 2008 .

35 Gašparović, S.: Zračni promet i turizam Primorske Hrvatske, Geoadria, 16(2) 2011, pp. 155-187.

36 Bilotkach, V., Gaggero, A. A., Piga, C. A.: Airline pricing under different market conditions: Evidence from European Low-Cost Carriers, Tourism Management, Vol. 47 2015, pp. 152-163.

37 Krajnović, A., Nekić, N., Bosna, J. Utjecaj niskotarifnih zrakoplovnih kompanija na gospodarstvo s posebnim osvrtom na turizam, Oeconomicus, 1(1) 2016, pp. 91-108. 
Mandić, Teklić and Petrić38 (2017) state that, although the expansion of LCCs coincides with the growth of tourist demand in Croatia (and the rest of the world), their emergence on the Croatian market happened relatively recently. In order to investigate the effects of the entrance of the LCCs on the Croatian market, the authors conducted a primary research with the aim of establishing their effect on the business success of the airports. LCCs bring a significant portion of income to the airports in question and this specifically concerns those along the Croatian coastline. The conclusion is, based on several factors, like the growing numbers of passengers in these airports and the data from the empirical research, that low-cost carriers bring more activity during the season, so they should be included in the strategies planned for future development of Croatian destinations.

Miočić, Klarin and Vidić39 (2018) investigate the profile and attitudes of the tourists, users of LCCs in Zadar and Zadar County on a random sample of 866 respondents that have spent at least two nights in Zadar County. The research results show the tourists act in line with the tourist trends and how their arrival is motivated by different elements, not just by "the sun and the sea", but they also want new experiences and adventures.

Lim and Lee ${ }^{40}$ (2019) compare the perception of the quality of the services of the conventional airline companies and the low-cost carriers. The competition between the conventional and the LCCs is stronger on the global market and many analyses confirm significant differences in the perception between the two types of companies. The authors base their conclusion that competition between the two has become fiercer on the LDA topic model. Naletina, Petljak and Sremac $^{41}$ (2019) conducted an empirical research on the satisfaction of the users of air traffic and the supporting services in Croatian airports. The results of the primary research suggest that when buying tickets, customers put the price and safety first. Users are not satisfied with the price-quality ratio of the service, as well as with the prices of parking and hospitality services offered at

38 Mandić, A., Telkić, M., Petrić, L.: The effects of the low cost carriers presence on airport performance: evidence from Croatia, Tourism and Hospitality Management, 23(1) 2017, pp. 17-34.

39 Miočić, B. K., Klarin, T., Vidić, G.: The application of sustainable tourism indicators: Evidence from Croatia, In Vrontis, D., Weber, Y., Valletta, T. (Eds.) Proceedings of 11th Annual Conference of the EuroMed Academy of Business: Research Advancements in National and Global Business Theory and Practice, 2018 (January), pp. 834-848.

40 Lim, J., Lee, H. C.: Comparisons of service quality perceptions between full service carriers and low cost carriers in airline travel, Current Issues in Tourism, 2019, pp. 1-16.

${ }_{41}$ Naletina, D., Petljak, K., Sremac, M.: Empirical research on user satisfaction with the transport and supporting services at Croatian airports, Pomorstvo, 33(1) 2019, pp. 92-101. 
the airports. Furthermore, customer satisfaction can be observed through three elements: additional services, user satisfaction with the additional services and user satisfaction with the staff and prices of additional services. In the conclusion, the authors state that, because of further development of air transport, special attention should be placed on safety and development of higher standard of air transport. Also, they point out that focus should be placed on satisfaction of the customers and on monitoring the quality, since these two elements lead to passengers.

\subsection{RESEARCH INSTRUMENT}

For the purposes of the paper, a primary research was conducted. A highly structured questionnaire with 34 questions was used as the research instrument. The respondents filled out the online questionnaire made in Google Docs. The questionnaire was divided into three parts. The first part consisted of 6 closed-ended questions about socio-demographic characteristics of the respondents (age, gender, residence, education, work status, income). The second part of the questionnaire was comprised of 21 questions focusing on establishing the frequency with which the respondents use the services of low-cost carriers, the reasons ... In the third part there were 7 questions. Two questions related to their opinions on the importance of specific factors when deciding on which airline to use. In those questions, the respondents expressed their level of agreement with the statements regarding their satisfaction with Croatian airports on the Likert scale $(1=$ strongly disagree, $2=$ disagree, $3=$ neutral, $4=$ agree and $5=$ strongly agree). Other questions ( 2 closed-ended and 3 open-ended questions) in the last part of the questionnaire, they expressed their attitude towards the chance for using the LCCs services in the future.

To gain as valid answers as possible, the authors used a combination of methods like the secondary and primary data analysis and personal interviews. Moreover, to make the questionnaire available to as many people, they shared the link leading to the questionnaire designed in Google Docs on social networks. The questionnaire was designed based on the previous research listed in the overview of the domestic and foreign literature.

\subsection{RESEARCH RESULTS}

216 respondents participated in the research. 52\% were male and $48 \%$ (103) female respondents. The biggest age group was between 18 and 35\%, with 206 respondents $(95.4 \%)$. Only 7 respondents were between the ages of 36 and 55,2 of them were below 18 and only 1 respondent was older than 56. Most 
respondents are students (38\%) and 34\% of them have a university degree. 46 respondents are with a high school diploma and 23 claim they have a $\mathrm{PhD}$ or a Master's degree. Only 2 of them said they had finished secondary education.

Graph 1. shows that most respondents that are employed have permanent employment (36\%). Then follow those that are employed through the Student Service Centre (32\%) and the fewest respondents have part-time jobs (4\%).

\section{Graph 1. Work status of the respondents}

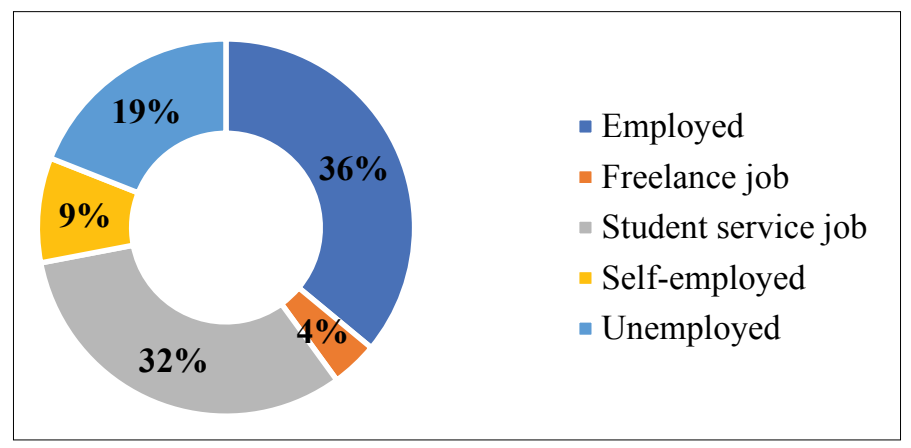

Source: primary research

If we look at the personal monthly income (Graph 2), we see that there is an equal share of those with the income between 1,501 and 3,500 HRK and those with the income between 5,501 and 7,500 HRK (21.30\%). There are 26 respondents without a monthly income (12.4\%).

\section{Graph 2. Personal monthly income}

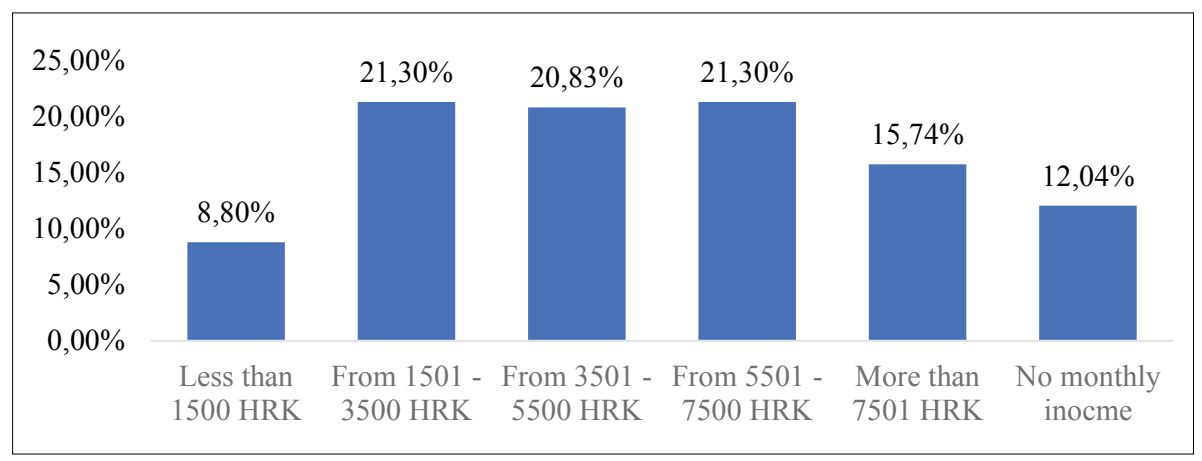

Source: primary research 
Research results show that most respondents prefer conventional/traditional airlines to low-cost carriers. 53\% of them prefer conventional/traditional companies, while $47 \%$ prefer LCCs. 127 (59\%) have used the services of a LCC (e.g. Ryanair) and 89 respondents (41\%) have not used their services. Regarding the quality of the services provided by the LCCs, 75 (35\%) respondents state they think the LCCs services are good, while the highest number of the respondents $(48 \%)$ say the service quality is questionable.

Graph 3 shows the airports that were most often used by the respondents for flying to the selected destinations. In the first place, there is Zagreb Airport with $42 \%$, followed by Zadar Airport with $26 \%$, Pula with $18 \%$ and others with $7 \%$. Also, $7 \%$ of the respondents have used other domestic airports, as well as foreign: Vienna, Budapest, Venice, Munich and Ljubljana.

\section{Graph 3. Airports chosen for flying to selected destinations}

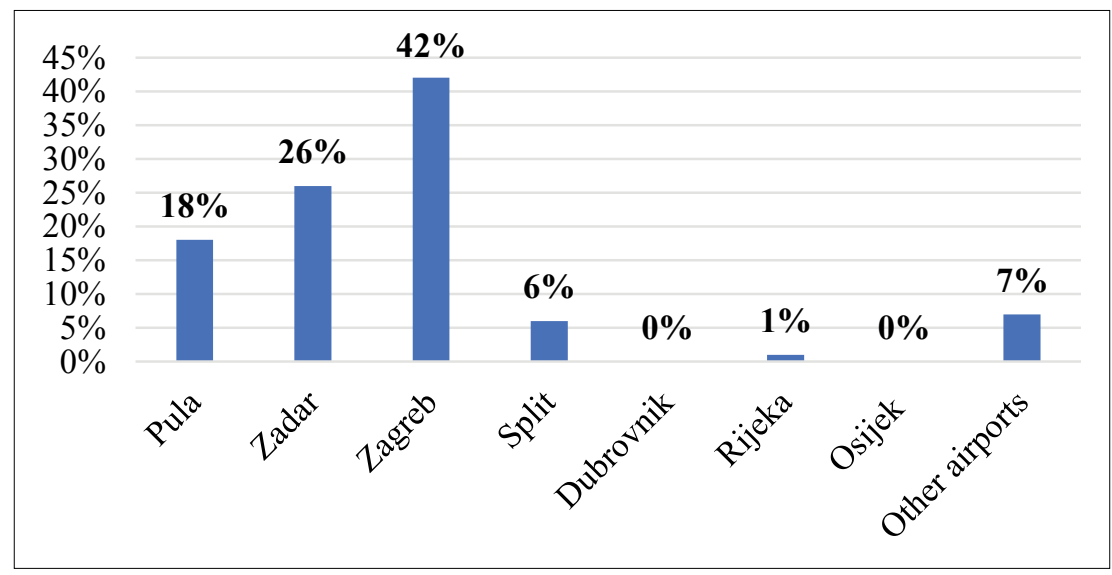

Source: primary research

Low-cost carriers the respondents have flown with from Pula Airport are presented in Graph 4. Ryanair is the leading carrier with 54\%, followed by Eurowings $(22 \%)$ and easyJet (18\%). 


\section{Graph 4. Low-cost carriers the respondents have flown with from Pula Airport}

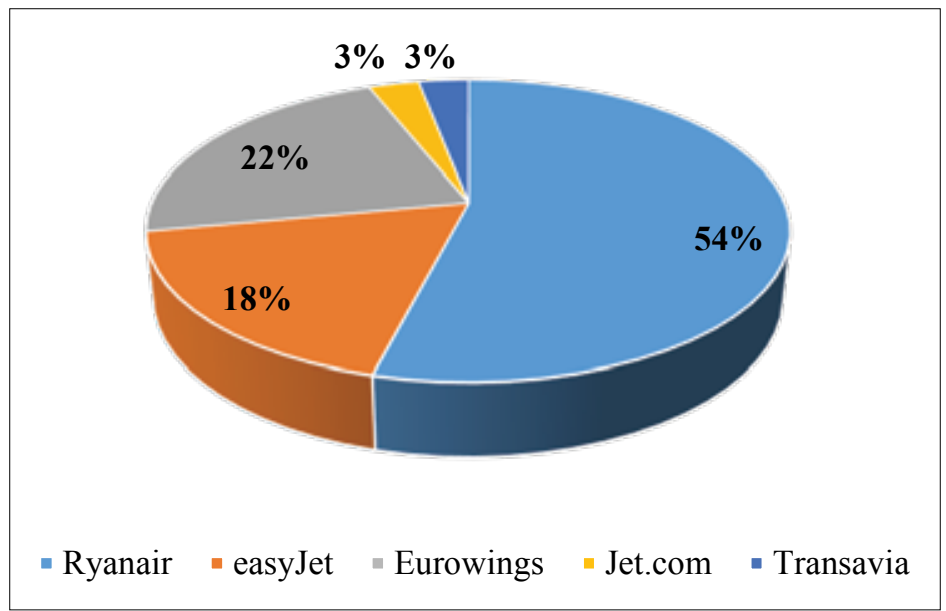

Source: primary research

Graph 5 displays the low-cost carriers the respondents have flown with from Zadar Airport. There, Ryanair holds the leading position with 61\%, and then there are Eurowings (4\%). Norwegian and Air Serbia have been used by $6 \%$ of the respondents.

\section{Graph 5. Low-cost carriers the respondents have flown with from Pula Airport}

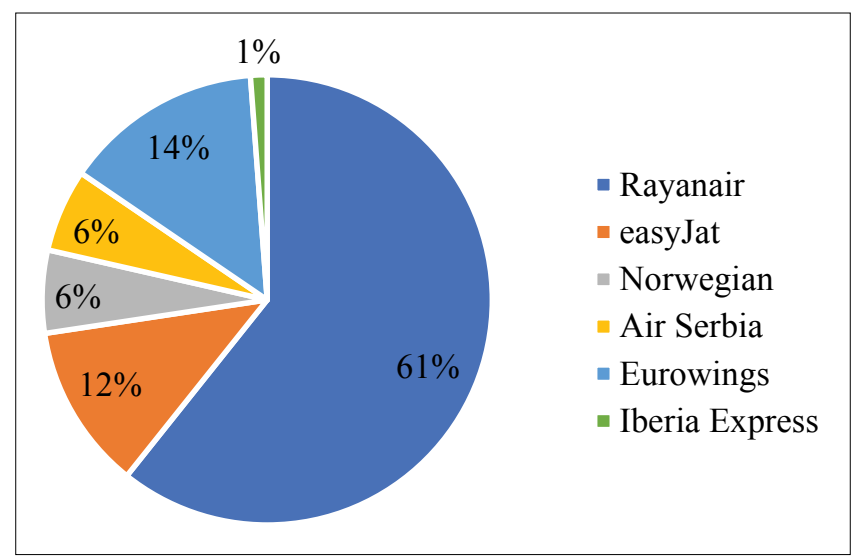

Source: primary research

The respondents state that they rarely (44\%) or sometimes use the LCC services. Only $12 \%$ of the respondents (Graph 22) use these services very often. 
Most of them say they use the services because of the affordable prices (66\%), and then there is the frequency of the flights (17\%), and the availability of the transport (11\%).

When deciding about which carrier to choose (Table 1), the respondents see the price as the most important factor, and then there is the possibility of booking them online and the availability of the destinations and the availability of the tickets. Since the very business policy of LCCs in relation to conventional airline companies lies in the low prices, it can be concluded that they employ their business strategy well. The respondents deem food and beverage offer as least important, which is in line with the business strategy of low-cost carriers because, as a rule, they do not offer such services.

Table 1. The importance of the factors influencing the process of decision-making about purchasing the ticket for the specific LCC

\begin{tabular}{|l|c|}
\hline FACTOR & MEAN \\
\hline Safety & 3.93 \\
\hline Speed & 3.72 \\
\hline Price & 4.28 \\
\hline Ticket availability & 3.98 \\
\hline Destination availability & 4.00 \\
\hline Staff service & 3.49 \\
\hline Food and beverage & 3.01 \\
\hline Cleanliness & 3.60 \\
\hline Commodity & 3.49 \\
\hline Punctuality & 3.82 \\
\hline Schedule and flight frequency & 3.80 \\
\hline Flight delay & 3.52 \\
\hline Web page transparency & 3.66 \\
\hline Online booking & 4.02 \\
\hline Payment mode & 3.95 \\
\hline Compensation for flight delay & 3.59 \\
\hline Additional service (e.g. additional baggage) & 3.57 \\
\hline Compensation for additional services (e.g. for additional baggage) & 3.55 \\
\hline Promotional activities & 3.34 \\
\hline LCCs reviews & 3.49 \\
\hline Loyalty programs & 3.23 \\
\hline Plane fleet used by the carriers & 3.37 \\
\hline Pre-flight services & 3.17 \\
\hline Access - the airport is on good location & 3.72 \\
\hline
\end{tabular}

Source: primary research 
Table 2 shows the level of user satisfaction with the LCC service. Most respondents are satisfied with the price of the ticket regarding the provided service and speed of buying the tickets via the Internet, then follow those satisfied with payment possibilities and good transparency of the web page. The fewest respondents are satisfied with the food and beverages.

\section{Table 2. User satisfaction with the LCC service}

\begin{tabular}{|l|c|}
\hline & MEAN \\
\hline Flight safety is at high level. & 3.67 \\
\hline I am satisfied with the ticket price considering the provided service. & 3.86 \\
\hline Staff service is at high level. & 3.58 \\
\hline I am satisfied with the served food and beverage. & 3.24 \\
\hline I am satisfied with the cleanliness. & 3.52 \\
\hline I am satisfied with the comfort during the flight. & 3.35 \\
\hline $\begin{array}{l}\text { I am satisfied with the punctuality of the departures and arrivals from } \\
\text { and to the selected destinations. }\end{array}$ & 3.60 \\
\hline I am satisfied with the availability of the destinations. & 3.59 \\
\hline I am satisfied with the schedule and the number of flights. & 3.63 \\
\hline I am satisfied with the payment possibilities. & 3.80 \\
\hline $\begin{array}{l}\text { I am satisfied with the offer od additional services (e.g. additional } \\
\text { baggage). }\end{array}$ & 3.45 \\
\hline $\begin{array}{l}\text { The compensation for additional services is acceptable e.g. } \\
\text { compensation for additional baggage). }\end{array}$ & 3.33 \\
\hline Good web page transparency. & 3.70 \\
\hline I am satisfied with the speed of buying tickets via the Internet. & 3.86 \\
\hline $\begin{array}{l}\text { I am satisfied with the speed customer service of the airline responds to } \\
\text { an inquiry. }\end{array}$ & 3.54 \\
\hline I am satisfied with the airplane fleet used by the LCCs. & 3.48 \\
\hline $\begin{array}{l}\text { I am satisfied with the access to the airport i.e. the airport used by the } \\
\text { LCCs is on good location. }\end{array}$ & 3.47 \\
\hline
\end{tabular}

Source: primary research 
Table 3. Important properties regarding preference of particular type of carrier

\begin{tabular}{|c|c|c|c|c|}
\hline \multicolumn{2}{|r|}{ Factor } & $\mathbf{N}$ & Mean & $\begin{array}{l}\text { P-value of } \\
\text { difference }\end{array}$ \\
\hline \multirow{2}{*}{ Flight delay } & LOW-COST CARRIER & 97 & 3.2268 & \multirow{2}{*}{.010} \\
\hline & CONVENTIONAL CARRIER & 113 & 3.0088 & \\
\hline \multirow{2}{*}{$\begin{array}{l}\text { Loyalty } \\
\text { programs }\end{array}$} & LOW-COST CARRIER & 97 & 4.5876 & \multirow{2}{*}{.000} \\
\hline & CONVENTIONAL CARRIER & 113 & 4.0088 & \\
\hline \multirow{2}{*}{$\begin{array}{l}\text { I am satisfied } \\
\text { with the flight } \\
\text { commodity }\end{array}$} & LOW-COST CARRIER & 97 & 3.5876 & \multirow[b]{2}{*}{.002} \\
\hline & CONVENTIONAL CARRIER & 113 & 3.4779 & \\
\hline \multirow{2}{*}{$\begin{array}{l}\text { Good web page } \\
\text { transparency }\end{array}$} & LOW-COST CARRIER & 97 & 3.3608 & \multirow[b]{2}{*}{.012} \\
\hline & CONVENTIONAL CARRIER & 113 & 3.3363 & \\
\hline \multirow{2}{*}{$\begin{array}{l}\text { I am satisfied } \\
\text { with the speed of } \\
\text { buying the tickets } \\
\text { online }\end{array}$} & LOW-COST CARRIER & 97 & 3.4948 & \multirow[b]{2}{*}{.012} \\
\hline & CONVENTIONAL CARRIER & 113 & 3.4956 & \\
\hline \multirow{2}{*}{ Cleanliness } & LOW-COST CARRIER & 97 & 3.4330 & \multirow{2}{*}{.007} \\
\hline & CONVENTIONAL CARRIER & 113 & 3.2920 & \\
\hline
\end{tabular}

Source: primary research

It is concluded that the key factors influencing user satisfaction with the LCC services are: flight delays, loyalty programs, commodity, web page transparency and cleanliness. But, as it can also be observed in Table D, the speed of completing the ticket purchase online at LCCs is not satisfactory. Low-cost carriers have to work on advancing the system for buying tickets online to ensure shorter time necessary for a successful purchase.

To establish whether there is a propensity to prefer LCCs because of the time when the ticket reservation will occur, the Chi-Square test was conducted, and the results (p.v. $=.0131$ ) show that this statement is not significant. Also, the same test was conducted to determine if there is a propensity to prefer LCCs regarding the level of income, and the results (p.v. $=.254$ ) suggest that this is also not the case. 
Table 4. Preference toward low-cost carriers dependent on location of the airport

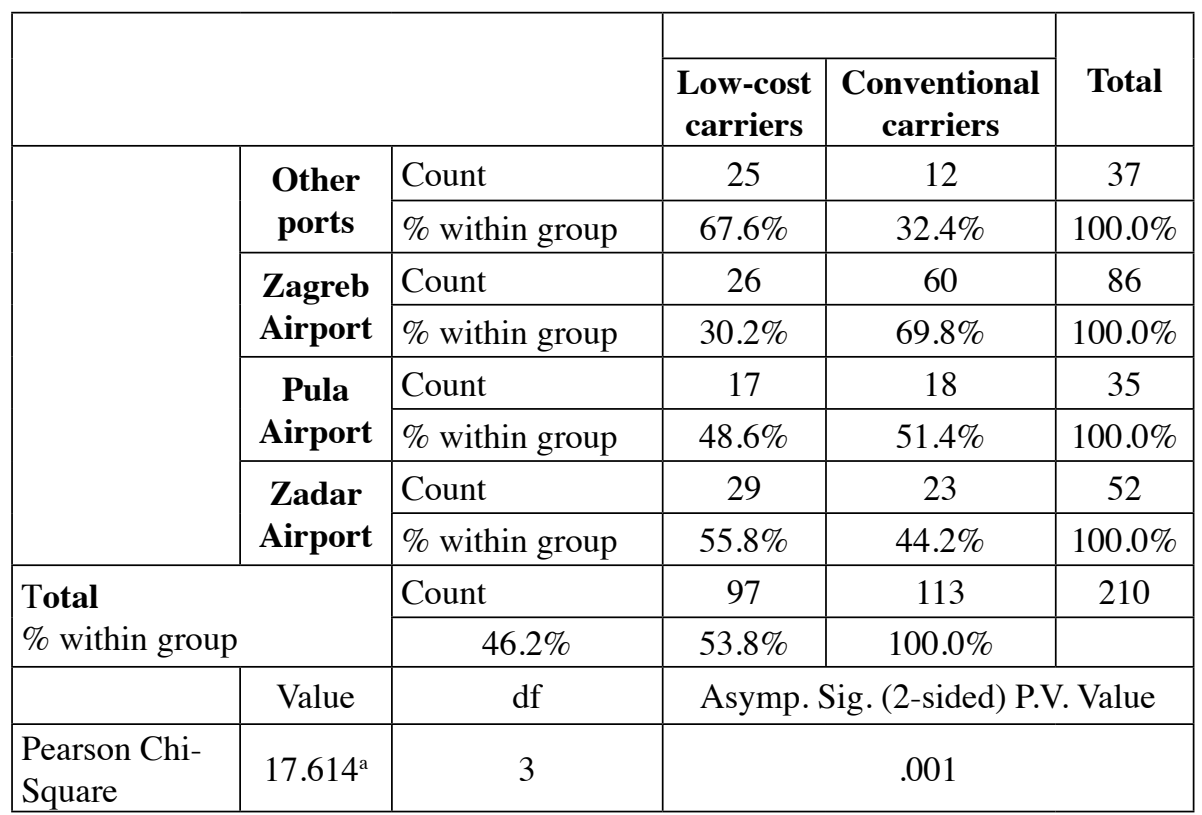

Source: primary research

Table 4 shows that there is a difference in the level of accepting LCCs depending on the airport. The respondents that use the services of Zadar and Pula Airports prefer the services of low-cost carriers while the passengers in Zagreb Airport prefer those of traditional airlines.

Out of 216 respondents, 193 (89\%) would recommend flying with a LCC, while $23(11 \%)$ would not. Some of the suggestions proposed by the respondents for improving the quality of the service are: to improve the safety, to improve the commodity, to become more accessible from urban areas and not only from towns or smaller cities, free baggage, better service quality etc. However, certain number of respondents thinks everything works well, and LCCs should not change anything.

\subsection{LIMITATIONS AND RECOMMENDATIONS FOR FUTURE RESEARCH}

There are several limitations to this research. First, the sample of 216 respondents is not a big sample to consider it relevant for the area of Croatia and then for the area beyond its borders. The conclusions based on the answers cannot 
be used in broader context. The research was conducted online via social networks, which represent a limitation because not all citizens possess an online profile, especially the elderly that might be the users of LCCs services.

Recommendations for further research are that the questionnaire be printed and distributed on the targeted locations (e.g. airports and tourist agencies), regardless of the modern $21^{\text {st }}$ century technologies. This could considerably lead to a higher response rate i.e. a bigger and more precise research sample. In line with that, the recommendation is to consider a larger geographical area, starting from Zagreb City County onward to other counties. Since the flights are characterized by high seasonality, the research should be conducted during the season and in the pre-and off-season period to better perceive the number of passengers and the number of flights that vary during the summer and winter months.

\section{CONCLUSION}

On the air transport market, during the last years, there have been many changes. Low-cost and traditional airline companies compete with the products that are very similar. The key difference between low-cost carriers and traditional airlines is in the services they provide. Traditional airline companies offer many different services, while LCCs offer only the basic ones. The goal of LCCs is to reduce costs, and traditional airlines base their service package on the ability of their customers to pay for the service. However, due to the rising competition on the market, the differences between low-cost carriers and traditional airline companies today are becoming smaller. As a tourist country, Croatia is exceptionally attractive to LCCs. Capacity utilization of the airports is not at the level where it should be and further development of LCCs is inevitable. The positive side is that the presence of LCCs on the Croatian market, especially on the coastline has been growing in the last years.

There are results of the primary research on user satisfaction with the services of low-cost carriers, especially regarding Pula and Zadar Airport. It is concluded that users are satisfied with the ticket price regarding the service, and with the speed of ticket purchasing via the Internet, as well as with the possibilities of payment. User dissatisfaction is mainly expressed regarding food and beverage offer and the charges for additional services (e.g. extra charges for additional baggage) supporting the business policy of LCCs for their future development. Likewise, it is concluded that low-cost carriers have to modernize their ticket-selling systems to improve the satisfaction of their users with the speed of the entire process of booking the tickets. 


\section{LITERATURE}

1. Akgüç, M., Beblavý, M., Simonelli, F.: Low-Cost Airlines. Bringing the EU closer together, Brussels: Centre for European Policy Studies, 2018, available at: https:// www.ceps.eu/wp-content/uploads/2018/05/LowCost\%20Airlines\%20Bringing\%20the\%20EU\%20closer\%20together.pdf (October 17, 2019).

2. Bilotkach, V., Gaggero, A. A., Piga, C. A.: Airline pricing under different market conditions: Evidence from European Low-Cost Carriers, Tourism Management, Vol. 47 2015, pp. 152-163.

-DOI: https://doi.org/10.1016/j.tourman.2014.09.015

3. Dobruszkes, F.: An analysis of European low-cost airlines and their networks, Journal of Transport Geography, 14(4), 2006, pp. 249-264.

-DOI: https://doi.org/10.1016/j.jtrangeo.2005.08.005

4. Gábor, D.: Low-cost Airlines in Europe: Network Structures After the Enlargement of the European Union, Geographica Pannonica, 14(2) 2010, pp. 49-58.

-DOI: https://doi.org/10.5937/GeoPan1002049D

5. Gašparović, S., Jakovčić, M., Vrbanc, M.: Hrvatske zračne luke u mreži europskih niskotarifnih kompanija, Geoadria, 17(1) 2012, pp. 93-109.

-DOI: https://doi.org/10.15291/geoadria.284

6. Gašparović, S.: Zračni promet i turizam Primorske Hrvatske, Geoadria, 16(2) 2011, pp. 155-187.

7. Graham, A., Papatheodorou, A., Forsyth, P.: Aviation and tourism: implications for leisure travel, 2008, Hampshire: Ashgate Publishing Ltd..

8. Hanlon, P.: Global airlines, 2006, Routledge.

-DOI: https://doi.org/10.4324/9780080456102

9. Krajnović, A., Bolfek, B., Nekić, N.: Low-cost strategija u zračnom prijevozu putnika, Oeconomica Jadertina, 4(2) 2014, pp. 3-32.

-DOI: https://doi.org/10.15291/oec.275

10. Krajnović, A., Nekić, N., Bosna, J. Utjecaj niskotarifnih zrakoplovnih kompanija na gospodarstvo s posebnim osvrtom na turizam, Oeconomicus, 1(1) 2016, pp. 91-108.

11. Lim, J., Lee, H. C.: Comparisons of service quality perceptions between full service carriers and low cost carriers in airline travel, Current Issues in Tourism, 2019, pp. 1-16.

-DOI: https://doi.org/10.1080/13683500.2019.1604638

12. Mandić, A., Telkić, M., Petrić, L.: The effects of the low cost carriers presence on airport performance: evidence from Croatia, Tourism and Hospitality Management, 23(1) 2017, pp. 17-34.

-DOI: https://doi.org/10.20867/thm.23.1.4 
13. Miočić, B. K., Klarin, T., Vidić, G.: The application of sustainable tourism indicators: Evidence from Croatia, In Vrontis, D., Weber, Y., Valletta, T. (Eds.) Proceedings of $11^{\text {th }}$ Annual Conference of the EuroMed Academy of Business: Research Advancements in National and Global Business Theory and Practice, 2018 (January), pp. 834-848.

14. Naletina, D., Petljak, K., Sremac, M.: Characteristics and the Overview of Air Traffic in the Republic of Croatia, Pomorstvo, 32(2) 2018, pp. 297-311.

-DOI: https://doi.org/10.31217/p.31.2.15

15. Naletina, D., Petljak, K., Sremac, M.: Empirical research on user satisfaction with the transport and supporting services at Croatian airports, Pomorstvo, 33(1) 2019, pp. 92-101.

-DOI: https://doi.org/10.31217/p.33.1.10

16. Page, S.: Transport and tourism: Global perspectives, 2005, Harlow: Pearson education.

17. Pender, L., Baum, T.: Have the frills really left the European airline industry?, International Journal of Tourism Research, 2(6) 2000, pp. 423-436.

-DOI: https://doi.org/10.1002/1522-1970(200011/12)2:6<423::AID-JTR240>3.0.CO;2-R

18. Sarilgan, E. A.: Impact of low Cost Carriers on Turkish Tourism Industry, Internationa Journal of Academic Research in Business and Social Science, 6(4) 2016, pp. 176-188.

-DOI: https://doi.org/10.6007/IJARBSS/v6-i4/2088

19. Štimac, I., Vidović, A., Sorić, V. Utjecaj niskotarifnih zrakoplovnih kompanija na prometne učinke Zračne luke Zagreb, $12^{\text {th }}$ International Conference on Transport Science -ICTS 2009 -Transport science, profession and practice, 2009, Available at: https://bib.irb.hr/datoteka/409248.Utjecaj_niskotarifnih_zrakoplovnih_kompanija_na_prometne_uinke_Zrane_luke_Zagreb.pdf (September 5, 2019).

20. Vidović, A., Steiner, S., Štimac, I.: Development potentials of low cost aviation in the Republic of Croatia, Promet - Traffic\&Transportation, 23(6) 2011, pp. 519527.

21. Vojvodić, K.: Europsko tržište niskotarifnih zračnih prijevoznika, Suvremeni promet, 26(5) 2006, pp. 363-366.

\section{ONLINE SOURCES:}

1. Anna Aero, https://www.anna.aero/2018/07/18/lcc-capacity-in-europe-set-forhalf-a-billion-seats-in-2018/ (September 3, 2019).

2. Manuell, R.: 8 reasons low cost carriers are so cheap (2017), 01.03.2017, https:// www.internationalairportreview.com/article/32697/low-cost-carriers/ (September 4, 2019).

3. Pula Airport, https://airport-pula.hr/ (August 8, 2019). 
4. Zadar Airport, https://www.zadar-airport.hr/ (August 8, 2019.).

5. Zadar Airport, statistics, https://www.zadar-airport.hr/statistika-prometa (September 3, 2019)

6. Pula Airport, statistics, https://airport-pula.hr/poslovno/o-zracnoj-luci/statistika/ (September 3, 2019).

7. European Commission DG Mobility and Transport, 2017, https://ec.europa.eu/ transport/modes/air/25years-eu-aviation_en (October, 12, 2019).

8. Glas Istre: Zračna luka Pula „napada“ lanjski povijesni rekord: Samo na krilima Easy Jeta ove godine stiže 150 tisuća putnika (2019), 27.06.2019, https://www.glasistre.hr/pula/zracna-luka-pula-napada-lanjski-povijesni-rekord-samo-na-krilima-easyjeta-ove-godine-stize-150-tisuca-putnika-591669 (September 4, 2019).

9. Poslovni dnevnik: U Hrvatsku dolazi još jedan niskotarifni zračni prijevoznik, 03.07.2019, http://www.poslovni.hr/trzista/u-hrvatsku-dolazi-jos-jedan-niskotarifni-zracni-prijevoznik-354992 (September 3, 2019).

10. https://www.exyuaviation.com/2019/07/low-cost-carriers-drive-croatias-record. html (October 24, 2019).

11. https://www.zadar-airport.hr/aci-zracna-luka-zadar-medju-5-najboljih-po-rastu-prometa (October 17, 2019) 
